\title{
Effects of Milking Frequency of Dairy Goats on Milk Yield and Composition and on System Profitability
}

\author{
Martinez GM${ }^{1 *}$, Suarez $\mathrm{VH}^{2}$,Alfaro $\mathrm{E}^{1}$ and Alfaro $\mathrm{J}^{1}$ \\ ${ }^{1}$ Estación Experimental Agropecuaria Salta-INTA, Argentina \\ ${ }_{2}^{2}$ Instituto de Investigación Animal del Chaco Semiárido-INTA, Argentina
}

Submission: September 01, 2017; Published: September 15, 2017

*Corresponding author: Martinez GM, Estación Experimental Agropecuaria Salta-INTA, Research Institute in Cerrillos, Salta, Argentina,

Tel: 54-387-5212004; Email: martinez.gabriela@inta.gob.ar

\begin{abstract}
The effects of once (1X) vs twice (2X) daily milking frequency on milk yield and chemical composition of multiparous Saanen biotype goats were evaluated during the second third of lactation. Goats were assigned to one of two treatment groups, once daily milking at 0500 (1X, $n=18$ ) and twice daily milking at 0500 and $1700(2 \mathrm{X}, \mathrm{n}=18)$. Milk yield and composition were recorded weekly during 12 wk. Differences in variables between groups were compared using an analysis of variance. Mean milk yield of X2 $(2.5 \pm$ ?) was significantly $(\mathrm{p}<0.05)$ higher than that of X1

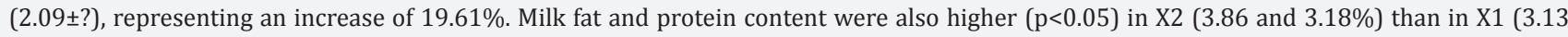
and $2.99 \%$ ). This study demonstrates a low to moderate increase in milk yield and quality under $2 \mathrm{X}$ during the second third of lactation in multiparous Saanen goats.
\end{abstract}

Keywords: Goat milk; Milking Effects; Cost effectiveness

Abbreviations: 1X: Once Milking; 2X: Twice Milking; W: Week; FCM: Fat Corrected Milk

\section{Introduction}

Intensive and semi-intensive dairy farms invest in automatic milking systems motivated by increased milk production per goat. Milking frequency is an important factor determining milk yield and quality of dairy goats that requires adequate feeding, welfare, health and environmental conditions [1]. The potential advantage of increased milking frequency for milk production and composition used to be main reason for applying this kind of management; nowadays, however, the production model that takes priority is one known as "low cost, high return"[1]. Since more frequent milking requires more variable costs, knowledge about the real increment of production per goat under a double milking system is necessary to decide if this practice will be adequate for each dairy system. For the twice daily milking frequency, increases in milk production of 6-18\% were reported for native Spanish goat breeds like Majorera, Murciano Granadina or Tarirfeña [2-4]. In Swiss breeds like Saanen and Alpine variable increments from 17 to $36 \%$ were documented $[2,5,6]$. The reported wide variation in milk yield may be attributed to different factors, such as breed, lactation stage, production level, and intervals between twice milking.
During intervals between milking, milk is stored in the lumen of alveoli, milk ducts, and udder cisterns. There are studies about the effect of twice (2X) vs. once (1X) milking a day on chemical composition of different milk fractions $[4,7,8]$; however, changes in the composition of the whole milk have been poorly studied. Torres et al. [8] indicated that fat content was the only milk component that presented variation with different milking frequency (3.86 once and vs. 4.38\% twice daily). Nevertheless, total solids percentage was not modified. Salama et al. [4] also reported changes in fat content, with the lowest percentage being obtained with twice daily milking ( 5.10 vs. $4.62 \%$ ). As a consequence, they concluded that animals subjected to this milking frequency presented a lower percentage of total solids.

The objective of the present study was to determine the effects of two milking frequencies (once vs twice daily) on milk yield and chemical composition of multiparous Saanen biotype goats during the second third of lactation under the northwestern Argentina system conditions. 


\section{Materials and Methods}

Thirty-six third or more parity Saanen goats with $90 \pm 5 \mathrm{~d}$ in milk born and reared at the National Institute of Agricultural Technology of Salta province, Argentina, were used for the present trial. Animals were allocated to the treatments (1X: once daily milking-2X: twice daily milking) based on average milk production of the first 90 days of lactation. Milking frequency before the experimental period was once daily. The experiment was conducted during $12 \mathrm{wk}$; goats were milked at $0500 \mathrm{~h}(1 \mathrm{X})$ or at $0500-1700 \mathrm{~h}(2 \mathrm{X})$. The animals had access to alfalfa pasture during milking intervals (0800-1630) and grazing management consisted of the allocation of daily plots by visual estimation of the availability of forage dry matter $(2000 \mathrm{~kg} / \mathrm{DM} / \mathrm{ha})$.

At the milking parlor, goats received $600 \mathrm{~g} / \mathrm{animal} / \mathrm{d}$ of corn and $20 \mathrm{~g} / \mathrm{animal} / \mathrm{d}$ of a vitamin-mineral corrector. Goats milked twice daily received the same ration but offered at two different

\section{Results and Discussion}

Table 1: Effect of milking frequency on milk yield and chemical composition in dairy goats $(n=36)$.

\begin{tabular}{|c|c|c|c|c|c|c|}
\hline \multirow{2}{*}{ Dependent Variable } & \multicolumn{2}{|c|}{ Milking Frequency } & \multirow{2}{*}{ SEM1 } & \multicolumn{2}{|c|}{$\begin{array}{c}\text { Milking } \\
\text { frequency (M) }\end{array}$} & Week (W) \\
\cline { 2 - 6 } & $\mathbf{1 X}$ & $\mathbf{2 X}$ & & $\mathbf{M} \mathbf{x} \mathbf{W}$ \\
\hline Milk yield (L/d) & $2.09 \mathrm{a}$ & $2.50 \mathrm{~b}$ & 0.06 & $<0.0001$ & 0.9602 & 0.9825 \\
\hline Milk fat \% & $3.13 \mathrm{a}$ & $3.86 \mathrm{~b}$ & 0.04 & $<0.0001$ & $<0.0001$ & $<0.0001$ \\
\hline Mil protein \% & $2.99 \mathrm{a}$ & $3.18 \mathrm{~b}$ & 0.02 & $<0.0001$ & $<0.0001$ & $<0.0001$ \\
\hline Milk lactose \% & $4.88 \mathrm{a}$ & $4.84 \mathrm{~b}$ & 0.02 & 0.0441 & 0.0484 & 0.7125 \\
\hline Milk non fat solids \% & 8.68 & 8.92 & 0.13 & 0.1749 & 0.4522 & 0.3792 \\
\hline Milk ash \% & $0.87 \mathrm{a}$ & $0.84 \mathrm{~b}$ & 0.004 & $<0.0001$ & $<0.0001$ & 0.2708 \\
\hline Milk fat content (g/d) & $64.84 \mathrm{a}$ & $94.36 \mathrm{~b}$ & 2.29 & $<0.0001$ & 0.0516 & 0.1707 \\
\hline Milk protein content (g/d) & $62.16 \mathrm{a}$ & $78.51 \mathrm{~b}$ & 1.89 & $<0.0001$ & 0.3477 & 0.9159 \\
\hline Milk lactose content (g/d) & $101.91 \mathrm{a}$ & $120.33 \mathrm{~b}$ & 3.09 & $<0.0001$ & 0.8989 & 0.9281 \\
\hline 4\% FCM2 & $1.81 \mathrm{a}$ & $2.41 \mathrm{~b}$ & 0.06 & $<0.0001$ & 0.4450 & $<0.0001$ \\
\hline
\end{tabular}

1 SEM: standard error of the mean.

${ }^{2} 4 \% \mathrm{FCM}=0.4(\mathrm{~L}$ of milk $)+15$ ( $\mathrm{kg}$ of fat $)$.

Means with a different letter within the same row are different $(P<0.05)$.

The results of the trial are shown in Table 1. Milking frequency treatments resulted in different milk yields between once and twice daily milking groups, but no differences were obtained between weeks. Figure 1 shows the evolution of mean milk yields throughout the trial. Although the trial began on day 90 post-partum, i.e. in the second third of lactation, $2 X$ obtained $19.61 \%$ more milk daily than $1 \mathrm{X}$; this percentage suggests an important difference considering the decrease in milk yield that occurs in the lactation curve from day 90 post-partum. However, other previous trials that began on the first post-partum days and that involved different goat breeds demonstrated similar differences, such as $18 \%$ with Murciano-Granadina [9] and 8-35\% with Alpine [6], and even a lower percentage (9.3\%) with Tinerfeña [3]. moments of the day. Before the experiment, goats were allowed $1 \mathrm{wk}$ of adaptation to milking frequency. Milk yields of individual goats were measured with an Mk 5 Waikato milk meter (direct measurement device; Waikato, Hamilton, New Zealand) every day during the 84 days of trial (12wk). Individual samples were taken once a week to measure milk composition (percentages of fat, protein, lactose, nonfat solids, ash). Milk samples (100ml) were obtained from the Waikato meters in the morning (1X) and in the evening and following morning $(2 \mathrm{X})$ milking treatments and were analyzed using the Lactostar Funke Gerber automatic analyzer.

Statistical analyses were performed using PROC MIXED of SAS (version 9.0; SAS Institute Inc., Cary NC). The model included fixed effects of milking frequency and week of trial and their interactions. Differences between milking frequencies were evaluated using a Tukey test. Statistical differences were considered significant at $\mathrm{P}<0.05$. 
and their metabolic activity. The rate at which they change may be influenced by farm management practices, such as milking frequency [10]. It has been suggested that once daily milking stimulates an accumulation of Feedback Inhibitor of Lactation (FIL) in the milk-producing alveoli, resulting in feedback inhibition of milk synthesis and secretion. Furthermore, frequent removal of milk $(2 \mathrm{X})$ from the gland minimizes local inhibitory effects of FIL and increases milk secretion [9-11].

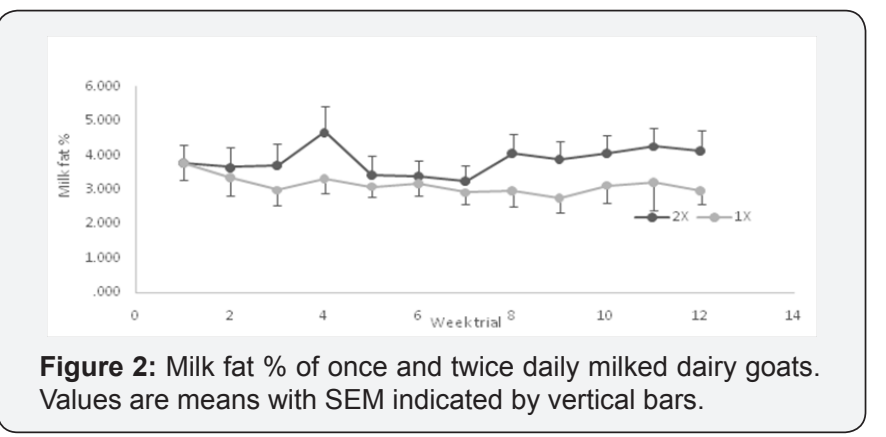

Results of milk composition showed that twice daily milking increased milk fat percentage significantly (Figure 2), with values differing between weeks (Table 1). Capote et al. [3,4] found that goats milked twice daily showed a significant increase in fat percentage compared with those milked once daily due to a higher proportion of alveolar milk removed in goats under the former frequency, which is richer in fat. These results were in disagreement with those found by Salama et al. [4], who reported that milk of $1 \mathrm{X}$ goats were more concentrated than milk of $2 \mathrm{X}$ goats (fat: 5.10 vs. $4.62 \%$, and casein 2.57 vs. $2.35 \%$ ).

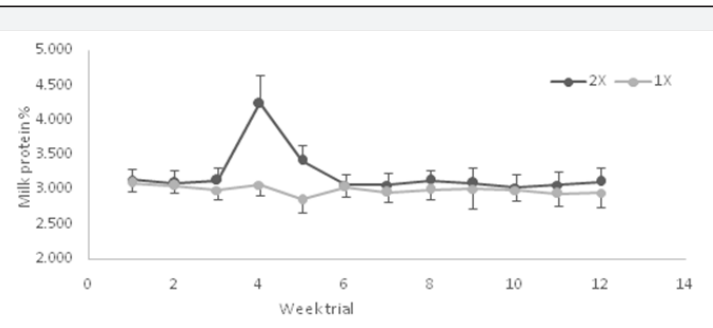

Figure 3: Milk protein $\%$ of dairy goat $1 \mathrm{X}$ or $2 \mathrm{X}$. Values are means with SEM indicated by vertical bars.

Milk protein percentage varied significantly between treatments and was greater in all weeks in $2 \mathrm{X}$ milked goats (Figure 3). In contrast, Salama et al. [4] and Capote et al. [7] did not find differences in milk protein content due to milking frequency, whereas Boutinaud et al. [5] showed a higher protein content in Saanen goats milked X1 than in X2 and X3 milked goats.

Total solids did not show significant differences between X1 and X2 milked goats (Table 1). Salama et al. [4] reported greater total solids for X2 (13.6 vs. 12.9\%). Milk total solids are a mixture of fat, protein, lactose and mineral matter. Thus, variations in these components can affect their concentration. In the present work, although milk fat was the most variable component between milking times, total solids percentages were not affected.

An important point in goat dairy system is profitability. In agreement with Salama et al. [4], Komara et al. [7] and Capote et al. [7], the present results showed on average $17.4 \%$ yield increase using twice daily milking. This gain in yield would not justify the change of system in the milking routine. For example, in Argentina the daily cost of energy, milking machine service and spare parts, labor, detergents, antisepsis and time spent for the second milking increase the costs by $66.4 \%$ over once daily milking. The milk yield increase obtained from the present trial $(19.6 \%)$ is far from covering and validating the difference in daily expenditures.

Another advantage to be considered is the working time that can be saved; dairy farmers always want to reduce their labor time to assign it to other activities and high labor costs make it impossible to take supplementary staff. Once-daily milking offers the possibility to reduce the work of dairy farmers because, for example, in French dairy cow farms the time spent milking in twice-daily milking represents about $50 \%$ of the daily labor time6. In the case of dairy goat farmers, this amount of time is allocated to manufacture and sell goat milk cheese [12-14].

\section{Conclusion}

This study demonstrates a moderate to low increase in milk yield and quality under twice daily milking during the second third of lactation in two liters-yielding Saanen goats. Under Argentina economic conditions, this management strategy, besides consuming more time, is not profitable for dairy goat farmers. Nevertheless, further investigations should be carried out to assess the magnitude of milk yield gains if twice daily milking is practiced during the first third of lactation of young and older goats.

\section{Ethics statement}

The procedures adopted has been approved by the Ethical Review Committee (CICUAL: Institutional Committee of Care and Use of Experimental Animals) of the University of La Plata, Argentina. There was no animal experimentation involved apart from normal system of goat production and our veterinary intervention.

\section{Conflict of Interest}

The authors declare that they have no conflict of interests on the writing and publishing of this manuscript.

\section{References}

1. Marnet PG, Komara M (2008) Management systems with extended milking intervals in ruminants: regulation of production and quality of milk. J Anim Sci 86: 47-56.

2. Capote J, López JL, Caja G, Peris S, Argüello A, Darmanin N (1999) The effects of milking once or twice daily throughout lactation on milk production of Canaria dairy goats. In Milking and Milk Production 
of Dairy Sheep and Goats. Barillet F, Zervas NP (Ed.s), Wageningen: Wageningen Pers, Netherlands pp. 267-273.

3. Capote J, Castro N, Caja G, Fernandez G, Morales-delaNuez A, et al. (2009) The effects of the milking frequency and milk production levels on milk partitioning in Tinerfeña dairy goats. Milchwissenschaft 64 239-241.

4. Salama AAK, Such X, Caja G, Rovai M, Casals R, et al. (2003) Effects of once versus twice daily milking throughout lactation on milk yield and milk composition in dairy goats. J Dairy Sci 86: 1673-1680.

5. Boutinaud M, Rousseau C, Keisler DH , Djiane J, Jammes H (2003) Growth hormone and milking frequency act differently on goat mammary gland in late lactation. J Dairy Sci 86: 509-520.

6. Komara M, Boutinaud M, Ben Chedly H, Guinard-Flament J, Marnet PG (2009) Once-daily milking effects in high-yielding Alpine dairy goats. ) Dairy Sci 92(11): 5447-5455.

7. Capote J, Castro N, Caja G, Fernandez G, Briggs H, et al. (2008) Effects of the frequency of milking and lactation stage on milk fractions and milk composition in Tinerfena dairy goats. Small Ruminant Research $75: 252-255$.

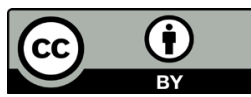

his work is licensed under Creative Commons Attribution 4.0 Licens

DOI: 10.19080/JDVS.2017.03.555616
8. Torres A, Castro N, Hernández-Castellano LE, Argüello A, Capote J (2013) Effects of milking frequency on udder morphology, milk partitioning, and milk quality in 3 dairy goat breeds. J Dairy Sci 96(2): 1071-1074.

9. Blatchford DR, Peaker M (1982) Effect of frequent milking on milk secretion during lactation in the goat: relation to factors which limit the rate of secretion. Q J Exp Physiol 67(2): 303-310.

10. Maltz E, Blatchford DR, Peaker M (1984) Efects of frequent milking on milk secretion and mammary blood flow in the goat. Q J Exp Physiol 69(1): 127-132.

11. Wilde CJ, Addey VCP, Boddy LM, Peaker M (1995) Autocrine regulation of milk secretion by a protein in milk. Biochem J 305(pt1): 51-58.

12. Chauvat S, Seegers J, The Nguyen B, Clément B (2003) Le travail d'astreinte en élevage bovin laitier. Institut de l'Elevage, Paris, France.

13. Stelwagen K (2001) Effect of Milking Frequency on Mammary Functioning and Shape of the Lactation Curve. J Dairy Sci 84: E204-E211.

14. Wilde CJ, Knight CH (1990) Milk yield and mammary function in goats during and after once-daily milking. J Dairy Res 57(4): 441-447.

\section{Your next submission with Juniper Publishers} will reach you the below assets

- Quality Editorial service

- Swift Peer Review

- Reprints availability

- E-prints Service

- Manuscript Podcast for convenient understanding

- Global attainment for your research

- Manuscript accessibility in different formats

( Pdf, E-pub, Full Text, Audio)

- Unceasing customer service

Track the below URL for one-step submission https://juniperpublishers.com/online-submission.php 